\title{
Protective Effect of Cocoa Seeds Extract Application on PCNA Expression in Albino Mice Receiving DMBA Exposure
}

\author{
Junia Kirana, Khairuddin Djawad, Siswanto Wahab \\ Department of Dermatology and Venereology, Hasanuddin University, Makassar, Indonesia
}

Email address:

kin_mayang@yahoo.com (J. Kirana)

\section{To cite this article:}

Junia Kirana, Khairuddin Djawad, Siswanto Wahab. Protective Effect of Cocoa Seeds Extract Application on PCNA Expression in Albino Mice Receiving DMBA Exposure. American Journal of Clinical and Experimental Medicine. Vol. 5, No. 4, 2017, pp. $102-107$. doi: 10.11648/j.ajcem.20170504.11

Received: February 28, 2017; Accepted: March 24, 2017; Published: June 2, 2017

\begin{abstract}
Skin cancer incidence is directly proportional to malignancies in other organs and represents a health problem. This study aims to evaluate the protective effect of topical cocoa extract application on PCNA expression in mice receiving DMBA exposure. This study was conducted in Animal Laboratory for DMBA administration and cocoa extract application, Bimolecular Laboratory of Hasanuddin University as the location of ELISA evaluation. The study used animal experimental method with pure experimental design to find out the role of topical cocoa seeds extract on the skin of mice receiving DMBA application in one week. Twenty mice were divided into 4 treatment groups: first group was control without skin protector, second group with ethanol application, third group with topical cocoa extract application 400 ppm, and fourth group was treated with $800 \mathrm{ppm}$ topical cocoa with $100 \mathrm{ug}$ DMBA exposure three times per week. After one week the treatment was terminated and skin biopsy was excised for PCNA expression evaluation using ELISA. Study findings indicate that 400 ppm and 800 ppm topical cocoa extract had a protective effect on PCNA expression with 400 ppm as the most effective dose.
\end{abstract}

Keywords: DMBA, Cocoa Extract, PCNA

\section{Introduction}

Skin tumor incidence in human skin has been increasing in the last twenty years and shows an increasing trend. [1] Skin cancer incidence is directly proportional to malignancies in other organs and represents a health problem. Further studies on mutations in human cancer proved the involvement of environmental carcinogen direct effect on several cancers, including skin cancers. Epidemiological data indicate a relationship between human cancers and lifestyle and diet, and various studies on mutation in cancers have proved the involvement of environmental carcinogen direct effect on their development. [2]

Skin tumor is divided into two main groups: benign skin tumor and malignant skin tumor or skin cancer. The benign skin tumors are the manifestation of the presence of congenital or acquired skin growth disorder, and the absence of metastasis or invasiveness. Benign skin tumors can grow expansively but not to the extent that can damage its surrounding tissues structures. This is due to the fact that benign tumors have capsules that separate between abnormal tumor cells and normal cells. In malignant skin tumor, there is less capsules, resulting in infiltration and damage the surrounding tissues. [3]

Carcinogen can increase the cancer risk by altering the cellular metabolism or damaging the DNA directly in the cells, that disturbing the biological process and inducing uncontrollable division and lead to cancer formation. [4].

Malignancy in skin is a process that develops in several steps, occurring due to accumulation of various genetic alterations, including overexpression of oncogenes and the loss of tumor suppressor gene function, resulting in control function disturbance in cell proliferation, apoptosis and angiogenesis. [5]. Chemical agent-related carcinogenesis in human cancer can be classified into initiation, promotion and progression. [6]

As a result of the presence of global warming, there is a depletion in ozone layer that facilitates the ultraviolet 
radiation (UV) to reach earth surface, potent mutagen and carcinogen, such as genotoxic polycyclic aromatic hydrocarbon $(\mathrm{PAH})$ that contribute to the increased risk of skin cancer in human and experimental animals. [7]

PAH model in skin carcinogenesis process is often used to observe the chemicals-induced skin cancer mechanism $[8,9]$. Several studies suggest that $\mathrm{PAH}$, such as 7,12dimethilbenz(a)anthracene (DMBA) that can induce carcinogenesis step as initiator, and resulted in specific mutation in H-ras oncogene when applied to skin $[8,10]$. The development of skin tumor due to DMBA application relates to the presence of DNA mutation and the balance of genes regulating apoptosis, namely genes playing role in cell death when the DNA damage is irreversible. $[8,11]$

The application of the chemical carcinogenic induces the development of reactive oxygen species (ROS) that will damage DNA, RNA, and protein through chemical reactions such as oxidation, nitration and halogenation that can increase mutation, alter the important proteins and enzymes functions. The ROS formation can occur in initiation, promotion and progression step through genotoxicity. [12]

Proliferating cell nuclear antigen (PCNA) protein is one of the central molecules responsible for decisions of life and death of the cell. The PCNA gene is induced by p53, while PCNA protein interacts with $\mathrm{p} 53$-controlle $\mathrm{d}$ proteins Gadd45, MyD118, CR6 and, most importantly, p21, in the process of deciding cell fate. If PCNA protein is present in abundance in the cell in the absence of p53, DNA replication occurs. On the other hand, if PCNA protein levels are high in the cell in the presence of p53, DNA repair takes place. If PCNA is rendered non-functional or is absent or present in low quantities in the cell, apoptosis occurs. [13]

Antioxidants can reduce or prevent tumor initiation by inhibiting the carcinogen formation or bu altering the detoxification process. [6]. Effective chemopreventive and chemotherapeutic agents are considered as one strategies using natural materials. [7]. Prevention of cancer disease related to mutation process can be achieved by avoiding carcinogenic agents exposure and by consuming protective factors, with recent approach referring to chemopreventive. [2]

One of the natural substances that have potent antioxidant effect is cocoa, containing abundant polyphenols, particularly flavonoid. An in vitro study in prostate cancerous cells indicated that cocoa polyphenol extract at concentration of $0.001-0.2 \%$ has ability to inhibit the metastatic and nonmetastatic cancerous cell growth, not effective in normal prostate cells. Cocoa prosianidin as an antioxidant has been proved to inhibit apoptosis process through inhibition of downregulation of Bcl-2 expression in $\mathrm{H}_{2} \mathrm{O}_{2}$-induced tissue. [14]

Cocoa was also reported to have antiproliferative effect through the decrease of extracellular regulated kinase level, protein kinase B and cyclin D1 together with proapoptotic effect as indicated by decreased Bcl-XL level and increased BAX level and caspase-3 activity. [15].

The usefulness of cocoa as an antioxidant is well known in many diseases, but its protective effect in topical application at various concentrations as antioxidant has not been frequently reported. This study was aimed to evaluate the protective effect of topical cocoa extract application on PCNA expression in mice receiving DMBA exposure.

\section{Material and Method}

\subsection{Location and Time}

This study was conducted in animal laboratory division of Faculty of Medicine, Hasanuddin University and Microbiological division of Faculty of Medicine, Hasanuddin University Makassar as the location for PNCA evaluation by ELISA. Study was conducted during February 2016.

\subsection{Design and Variables}

This study was an animal experimental study with pure experimental design. Study variables consisted of: independent variable (cocoa extract), controlled variables (age, strain, sex, feed, cage temperature, and DMBA), intermediate variables (ROS, DNA damage, P53 expression), and dependent variable (PCNA expression).

\subsection{Population and Sample}

Population of this study was the healthy and non-pregnant female albino mice with average weight of 20-30 grams, derived from Laboratory of Research And Development Body of Maros. Mice were maintained for one week in standard conditions, namely: temperature $28 \pm 2^{\circ} \mathrm{C}$, humidity $50 \pm 10^{\circ} \mathrm{C}$ with light/dark cycle interval 12 hours. The study samples were healthy and non-pregnant female albino mice with average body weight of 20-30 grams.

\subsection{Data Collection}

20 healthy ad non-pregnant female albino mice were divided into 4 groups with each group consisted of 5 mice. Group 1 was a control group without skin protection, 3x DMBA 100 ug, group 2 was a control group with ethanol application and 3x DMB $100 \mathrm{ug}$, group 3 was provided with $400 \mathrm{ppm}$ cocoa extract and 3x DMBA $100 \mathrm{ug}$, and group 4 was treated with $800 \mathrm{ppm}$ cocoa extract and 3x DMBA 100 ug. After the termination of treatment, mice were evaluated for PCNA by using ELISA.

\subsection{Data Analysis}

The collected data in this study were then tabulated and prpocessed into computer software, SPP 21, and then analyzed descriptively and analytically. Analysis results were presented in the forms of tables and graphics with descriptions.

\section{Results}

This study involved 20 albino mice that were divided into four treatment groups. First group was a control group with 5 
mice with skin protection and exposed to DMBA 10 ug 3 times in a week. The second group consisted of 5 mice treated with ethanol and DMBA 100 ug exposure 3 times in a week. Third group was treated with 400 ppm topical cocoa seeds extract and exposed to 100 ug DMA 3 times in a week. And fourth group was treated with 800 ppm cocoa seeds extract and DMBA 100 ug exposure 3 times in a week. After one week, all mice were terminated and excision biopsies were performed (Table 1).

Table 1. Groups of mice receiving treatment.

\begin{tabular}{lll}
\hline Group & N & \% \\
\hline Control & 4 & 18.2 \\
Ethanol & 5 & 22.7 \\
Cocoa 400 & 5 & 22.7 \\
Cocoa 800 & 4 & 18.2 \\
Without treatment & 4 & 18.2 \\
Total & 22 & 100.0 \\
\hline
\end{tabular}

According to PCNA expression comparison by group, it was observed that there was a significant difference in PCA expression in each treatment group. PCNA expression was highest in mice treated with ethanol and $100 \mathrm{ug}$ DMBA exposure 3 times per week and lowest in mice treated with
800 ppm topical cocoa seeds extract and 100 ug DMBA exposure 3 times per week (Table 2).

Table 2. Comparison of PCNA Expression by Group.

\begin{tabular}{lllllll}
\hline Group & N & Minimum & Maximum & Median & Mean & SD \\
\hline Control & 4 & 23,30 & 81,51 & 32,915 & 42,660 & 26,333 \\
Ethanol & 5 & 38,35 & 75,78 & 44,680 & 49,808 & 14,947 \\
Cocoa 400 & 5 & 8,55 & 23,52 & 16,390 & 15,932 & 5,777 \\
Cocoa 800 & 4 & 4,23 & 19,99 & 10,525 & 11,318 & 8,039 \\
Without & 4 & 8,98 & 70,53 & 14,020 & 26,888 & 29,198 \\
treatment & & & & & \\
\hline
\end{tabular}

Kruskal-Wallis test $(\mathrm{p}=0,015)$

Note: There is a significant difference in mean of PCNA level by group $(p<0.05)$, the highest PCNA mean was observed in ethanol group (49.808) and lowest in Cocoa 800 group (11.318)

The comparison of PCNA expression between groups indicated that the groups with significantly different PCNA level were: control and cocoa 400 (cocoa 400 has lower PCNA mean than control), control and cocoa 800 (cocoa 800 has lower PCNA mean than control), ethanol and cocoa 400 (cocoa 400 has lower PCNA mean than ethanol) and ethanol and cocoa 800 group (cocoa 800 has lower PCNA mean than ethanol) (Table 3).

Table 3. Perbandingan antar Kelompok Menurut Ekspresi PCNA.

\begin{tabular}{|c|c|c|c|}
\hline \multirow{2}{*}{ (I) Kelompok } & \multirow{2}{*}{ (J) Kelompok } & \multicolumn{2}{|l|}{ LSD } \\
\hline & & Mean Difference (I-J) & $\mathbf{p}$ \\
\hline \multirow{4}{*}{ Control } & Ethanol & -7.148 & 0.573 \\
\hline & Cocoa 400 & $26.728^{*}$ & 0.047 \\
\hline & Cocoa 800 & $31.343^{*}$ & 0.029 \\
\hline & Without treatment & 15.773 & 0.246 \\
\hline \multirow{4}{*}{ Ethanol } & Ethanol & 7.148 & 0.573 \\
\hline & Cocoa 400 & $33.876^{*}$ & 0.010 \\
\hline & Cocoa 800 & $38.491^{*}$ & 0.007 \\
\hline & Without treatment & 22.921 & 0.083 \\
\hline \multirow{4}{*}{ Cocoa 400} & Ethanol & $-26.728^{*}$ & 0.047 \\
\hline & Cocoa 400 & $-33.876^{*}$ & 0.010 \\
\hline & Cocoa 800 & 4.615 & 0.716 \\
\hline & Without treatment & -10.956 & 0.391 \\
\hline \multirow{4}{*}{ Cocoa 800} & Ethanol & $-31.343^{*}$ & 0.029 \\
\hline & Cocoa 400 & $-38.491^{*}$ & 0.007 \\
\hline & Cocoa 800 & -4.615 & 0.716 \\
\hline & Without treatment & -15.570 & 0.252 \\
\hline \multirow{4}{*}{ Without treatment } & Control & -15.773 & 0.246 \\
\hline & Ethanol & -22.921 & 0.083 \\
\hline & Cocoa 400 & 10.956 & 0.391 \\
\hline & Cocoa 800 & 15.570 & 0.252 \\
\hline
\end{tabular}

*. The mean difference is significant at the 0.05 level.

Notes:

Groups with significantly different PCNA level:

a. Control - Cocoa 400 (Cocoa 400 has lower PCNA mean than control)

b. Control - Cocoa 800 (Cocoa 800 has lower PCNA mean than control)

c. Ethanol - Cocoa 400 (Cocoa 400 has lower PCNA mean than Ethanol)

d. Ethanol - Cocoa 800 (Cocoa 800 has lower PCNA mean than Ethanol)
Ethanol group was significantly different from cocoa 400 group $(\mathrm{p}<0.05)$, where the PCNA expression was lower than that in Cocoa 400 group (15.93) compared to ethanol group (49.81). Ethanol group was significantly different from cocoa 800 group $) \mathrm{p}<0.05)$, where the PCNA expression was significantly lower than cocoa 800 group (11.32) compared to ethanol group (49.81). Cocoa 400 group was not significantly different from cocoa $800(\mathrm{p}>0.05)$, but there was a trend where PCNA expression was lower in Cocoa 800 group (11.32) compared to Cocoa 400 group (15.93) (Figure 1). 


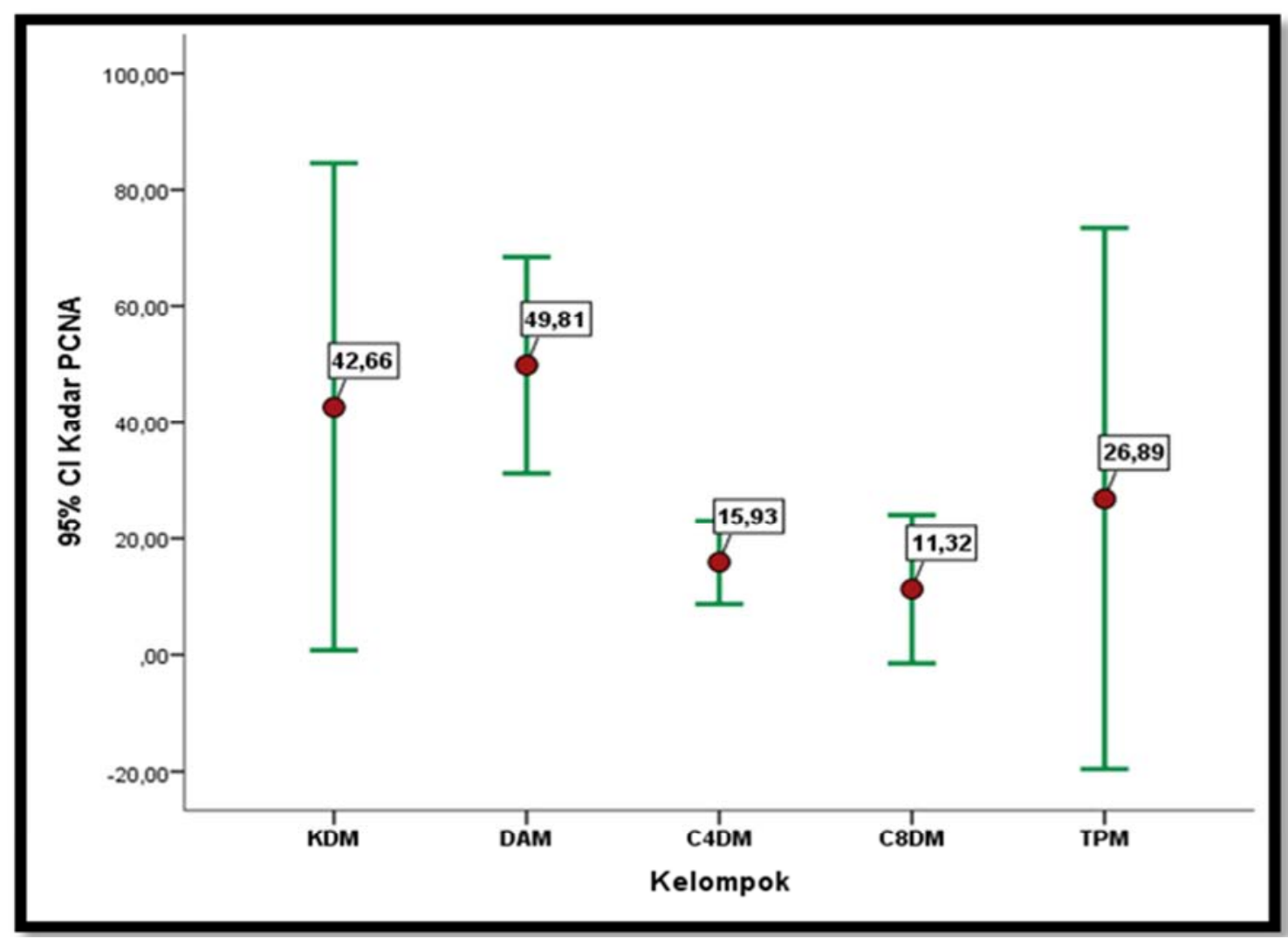

Figure 1. Comparison of PCNA expression by group.

\section{Discussion}

This experimental study evaluates the albino mice strain receiving DMBA exposure with cocoa extract application at various concentration topically and its effect on PCNA. This study involved 22 albino mice that were divided into five treatment groups: control group consisted of 4 mice without skin protection and provided with 100 ug DMBA exposure 3 times per week, second group consisted of 5 mice receiving ethanol and 100 ug DMBA exposure 3 times per week, third group consisted of 5 mice receiving $400 \mathrm{ppm}$ topical cocoa seeds extract and 100 um DMBA exposure 3 times per week, fourth group consisted of 4 mice receiving $800 \mathrm{ppm}$ topical cocoa seeds extract and 100 um DMBA exposure 3 times per week, and the last group consisted of 4 mice without treatment. After one week, all the mice were slaughtered and excision biopsy was performed.

This study used albino mice strain that were divided into several treatment groups and evaluated for PCNA level. Some of the factors affecting the carcinogenesis are mice strain vulnerability, the presence of genetic mutation, and appropriate initiation and promotion dosage. Mice strains have different sensitivity and tendency to develop a tumor from various chemical carcinogens. This indicates the presence of strain-dependent susceptibility that is determined by congenital genetic factors. A study reported that one time DMBA exposure followed by repeated exposure with TPA resulted in papilloma $100 \%$ and $53 \%$ in SENCAR strain and
CD-1 (Swiss albino) strain, whereas the strain FVB/N showed only $25 \%$ and BALB/c $17 \%$. The SENCAR strain had been reported as the most sensitive mice variant in various studies on carcinogenesis. [11]

The use of cocoa extract topically at various concentrations in this study was intended to know the effect of topical cocoa extract in the prevention of carcinogenesis. Dietary or topical cocoa extract with its various polyphenol components is a natural chemopreventive agent and potential therapy in the prevention of a malignancy. Studies have shown that flavonoids contained in cocoa have several biological functions that are important in vitro or in vivo with ability to remove free radicals or through transduction signal pathway regulation to stimulate apoptosis process and inhibit inflammation, cellular proliferation, angiogenesis and metastasis. [16]

This study evaluated the expression of Proliferating Cell Nuclear Antigen (PCNA) in albino mice after DMBA exposure with several treatments before. PCNA is a protein affecting the main DNA application and improve all processes in cell. This protein plays a role in sliding camp rom DNA polymerase and has function in the viability or death of a cell. [13]. PCNA expression increases its level with the severity of malignancy in various types of carcinoma, particularly epidermoid carcinoma.

This study findings indicate that there was a significant difference in PCA expression between treatment groups. The highest PCNA expression was observed in group treated with 
ethanol and $100 \mathrm{ug}$ DMBA exposure 3 times per week and the lowest was observed in group treated with $800 \mathrm{ppm}$ topical cocoa seeds extract and 100 ug DMBA exposure 3 times per week. Cocoa has antioxidant and anticancer effect, rich in antioxidant substance polyphenol (flavonoid). Several studies suggested that flavonoid has wide biological activities related to antitumor effect, including the inhibition of kinas and transcription factors. Flavonoid also has antiproliferative activity, induces apoptosis, and inhibit angiogenesis process. [17]

Some of the recent studies indicated that natural components of various plants such as cocoa, curcuma, green tea, soya and others have ability to prevent and cure cancer, through modulation of some signaling pathways, having some biological activities such as antiproliferative, proapoptotic and anti-angiogenic, so it can halt the carcinogenesis process. [18]

Polyphenol compounds contained in cocoa extract have been identified to have chemopreventive effect, through several mechanisms including antiproliferation, induction of apoptosis, oxidation prevention, detoxification enzyme induction, host immune system regulation, antiinflammatory activity, and prevention of cellular signal that can produce carcinovenesis [19]. The application of cocoa extract before oxidative stress prevented DNA damage and increased the activity of antioxidant enzyme glutathion reductase and glutatihion peroxidase in cells induced with pro-oxidant, tetrabuthylhydroperoxide. [20].

Immunohistochemistry evaluation such as PCNA is useful in determining the presence of proliferation marker and cell differentiation. PCNA is a protein helping DNA polymerase, as a key protein in the regulation of cell cycle and an inducer of proliferation cell differentiation. Several studies indicated that PCNA expression has different level in each normal cells, precancerous cells, and malignant cells. In the progression of a malignancy, PCNA expression increases, so its evaluation can be used to evaluate a progression of malignancy [21]. In accordance with literature, this study found that the higher the applied antioxidant level (800 ppm cocoa seeds extract), the higher the antioxidant value, making the PCNA expression useful to assess the presence of cell proliferation and differentiation and the progression of tumor cells is lower.

Several studies have been conducted in Makassar on the benefits of cocoa seeds extract on carcinogenesis process in experimental animals (mice). The application of topical cocoa extract before DMB/TPA exposure in albino mice had a protective effect on skin tumor through the oxidative stress and Bcl-2 inhibition at initiation stage and oxidative stress induction and $\mathrm{Bcl}-2$ in promotion stage. [22]

Cocoa extract has a protective effect on ultraviolet radiation through the inhibition of $8-\mathrm{OHdG}$ expression and PCNA expression with 200 ppm daily dosage. Study also suggested that increased cocoa extract dosage had no significant effect on protection against ultraviolet radiation. [23]

The study on experimental animals regarding the effect of
DMBA compound administration against the formation of skin tumor/malignancy indicated increased DMBA exposure frequency increased the dysplasia grade in albino mice skin, with most optimal initiation dosage in skin tumor development is 50 ug DMBA with frequency 3 times with 3 days application consecutively in a week [24]. Other studies indicated that there was a significant effect of DMBA exposure frequency on histopathological features of albino mice skin, the higher the frequency of DMBA exposure, the higher the squamous cell carcinoma growth, with highest frequency of $100 \mathrm{ug}$ DMBA exposure in $5 \mathrm{uL}$ acetone at frequency of 16 times, twice in a week for eight weeks [25].

\section{Conclusion and Suggestion}

This study concludes that DMBA application induces the PCNA expression in albino mice. Cocoa extract inhibits the PCNA expression, and the best dosage of cocoa extract is $400 \mathrm{ppm}$. This study suggests that further studies are needed by using the DMBA application at various dosages and time.

\section{List of Abbreviations}

$\begin{array}{ll}\text { PCNA: } & \text { Proliferating Cell Nuclear Antigen } \\ \text { DMBA: } & \text { 7,12-dimethylbenz(a)anthracene } \\ \text { ROS: } & \text { Reactive Oxygen Species } \\ \text { UNHAS: } & \text { Hasanuddin University } \\ \text { PAH: } & \text { Polycyclic Aromatic Hydrocarbon } \\ \text { ELISA: } & \text { Enzyme-Linked Immunosorbent Assay }\end{array}$

\section{References}

[1] Wei, H., Saladi, R., Lu, Y., Wang, Y., Palep, S. R., Moore, J., Phelps, R., Shyong, E. \& Lebwohl, M. G., Isoflavone Genistein: Photoprotection and Clinical Implications in Dermatology. J Nutr, 2003. 133: p.3811S-9S.

[2] Nigam, N. \& Shukla, Y., Preventive effects of diallyl sulfide on 7, 12-dimethylbenz[a]anthracene induced DNA alkylation damage in mouse skin. Mol Nutr Food Res, 2007. 51: p. 132428 .

[3] Hafner, C., Hartmann, A., Oerss, J. M., Stoehr, R., Zwarthoff, E. C., Hofstaedter, F., Landthaler, M., Vogt, T. FGFR3 Mutations in SebortheicKeratoses are already present in flat lesions and associated with age and localization. Modern Pathology, 2007. 20: p.895-03.

[4] Sularsito, S. A., Etiologi dan Patogenesis Kanker Kulit dalam Cipto, H., Pratomo, U. S., Handayani, I., \& Sukarata, K., (Eds). Deteksi dan Penatalaksanaan Kanker Kulit Dini, Jakarta: FK-UI. 2001.

[5] Muchtar, S. V., Iskandar, F., Amiruddin, M. D., Basal Cell Carcinoma at Dermatovenereology Clinic Dr. Wahidin Sudirohusodo General Hospital Makassar. Jogjakarta: SEAWPIT. 2000.

[6] Dulgosz, A. A. \& Yuspa, S. H. Carcinogenesis: Chemical. in Wolff, K., Goldsmith, L. A., Katz, S. I., Gilchrest, B. A., Paller, A. S. \& Leffel, D. J. (Eds.) Fitzpatrick's Dermatology in General Medicine. 7 ed. New York: Mc Graw Hill. 2008. 
[7] Meeran, S. M., Vaid, M., Punathil, T. \& Katiyar, S., Dietary grape seed proanthocyanidins inhibit 12-O-tetradecanoyl phorbol-13-acetatecausedskin tumor promotion in 7,12dimethylbenz[a]anthracene-initiated mouse skin, which is associated with the inhibition of inflammatory responses. Carcinogenesis, 2009. 30: p. 520-8.

[8] Yusuf, N., Nasti, T. H., Meleth, S. \& Elmets, C. A., Resveratrol enhances cell-mediated immune response to DMBA through TLR4 and prevents DMBA induced cutaneous carcinogenesis. Mol Carcinog, 2009. 48: p.713-23.

[9] Rastogi, S., Shukla, Y., Paul, B. N., Chodwuri, D. K., Khanna, S. K. \& Das, M., Protective effect of Omicum sanctum on 3 methylcholanthrene, 7,12-dimethylbenz(a)anthracene and aflatoxin B1 induced skin tumorigenesis in mice. Toxic Pharmacol, 2007. 224: p. 228-40

[10] Mcgrath, J. A., Eady, R. A. J. \& Pope, F. M., Anatomy and Organization of Human Skin. In Burns, T., Breathnach, S., Cox, N. \& Griffiths, C., (Eds.) Rook's Textbook of Dermatology. Massachusetts, Blackwell. 2004.

[11] Filler, R. B., Roberts, S. J. \& Girardi, M. Cutaneous TwoStage Chemical Carcinogenesis. Protoc, 2007. 18: p.1-5.

[12] Aydin, H., Baran, A., Aktas, A., Demir, K., Sahin, E., Kayar, A., Pabuccuoglu, S. \& Daglioglu, S. Effects of Soybean Extract and L-Tryptophan on 2,4-Dichlorophenol Induced Testicular Toxicity in Mice. J Animal Vet Adv, 2009. 8: p.7748.

[13] Paunescu, T., Mittal, S., Protic, M., Oryhon, J., Korolev, S. V., Joachimiak, A. \& Woloschak, E., Proliferating cell nuclear antigen (PCNA): ring master of the genome. Int J Radiat Biol, 2001. 77: p.107-21.

[14] El-Sherry, M. I., Zaher, M. A., Youssef, M. S. E. D. M. \& ElAmir, Y. O. Green tea treatment of Ultraviolet-B (UVB) Skin Carcinogenesis in Mice. Cancer Therapy, 2007.5: p.301-8.

[15] Roomi, M. W., Roomi, N. W., Kalinovsky, T., Ivanov, V., Rath, M. \& Niedzwiecki, A., Inhibition of 7,12dimethylbenzanthracene-induced skin tumors by a nutrient mixture. Med Oncol, 2008. 25: p. 333-40.

[16] Martin, M. A., Serrano, A. B. G., Ramos, S., et al, Protection of Human HepG2 Cells against Oxidative Stress by Cocoa Phenolic Extract. J. Agric. Food Chem, 2008. 56: p.7765-72.
[17] Baharum, Z., Akim, A. M., Hin, T. Y. Y., Hamid, R. A. \& Kasran, R. Theobroma cacao: Review of the Extraction, Isolation, and Bioassay of Its Potential Anti-cancer Compounds. Tropical Life Sciences Research, 2016. 27(1): p. 21-42.

[18] Lewandowska, U., Gorlach, S., Owczarek, K., Hrabec, E., Szewczyk, K. Synergistic Interactions Between Anticancer Chemotherapeutics and Phenolic Compounds and Anticancer Synergy Between Polyphenols. PostepyHig Med Dosw, 2014. 68: p.528-40.

[19] Mushtaq, M. \& Wani, S. M., Polyphenols and Human Health : A Review. Int J Pharm Bio Sci, 2013. 4(2): 338-60.

[20] Martin, M. A., Goya, L., Ramos, S., Preventive Effects of Cocoa and Cocoa Antioxidantsin Colon Cancer. Diseases, 2016. 4: p1-14.

[21] Cheng, H. C., Chien, H., Liao, C. H., Yang, Y. Y., Huang, S. Y. Carotenoids Suppressed Proliferating Cell Nuclear Antigen and Cyclin D1Expression in Oral Carcinogenic Models. $J$ of Taipei Med Univ, 2011. 3: p.1-14.

[22] Wahab, S., Topical Application of Cocoa Extract As Protective From Skin Tumor After Exposure to Compound 7,12dimethylbenz (a) Anthracene (DMBA) and 12-0tetradecanoylphorbol-13-acetate(TPA) in Albino Mice Study on Malondialdehyde (MDA), Expression of bcl-2 and Histopathology. Makassar: Program Pasca Sarjana Universitas Hasanuddin. 2014.

[23] Adriani, A., Armin, S. A., Massi, M. N., Djawad, K. Protective Effects of Daily Topical Cocoa Extract to the Expression of 8-OHdG and PCNA on UVB-Exposed Albino Mice. Int J Biol Med Res, 2010. 5(4): p.4607-11.

[24] Anwar, C., Djawad, K., Anwar, A. I. Impact of Compound Administration Frequency 7, 12 Dimethylbenz(A) Anthracene (DMBA) On The Skin Tumour Formation Albino Mice After Administration of 12-Tetradecanoylphorbol-13-Acetate. Makassar: Program Pasca Sarjana Universitas Hasanuddin. 2013.

[25] Muchsin, D., Djawad, K., Mappiasse, A. A., The Impact of The Frequency of 7, 12- Dimethylbenz (A) Anthracene (DMBA) Administration On The Formation of Dysplasia and Squamous Cell Carcinoma On The Skin of Albino Mice. Makassar: Program Pasca Sarjana Biomedik Universitas Hasanuddin. 2016. 